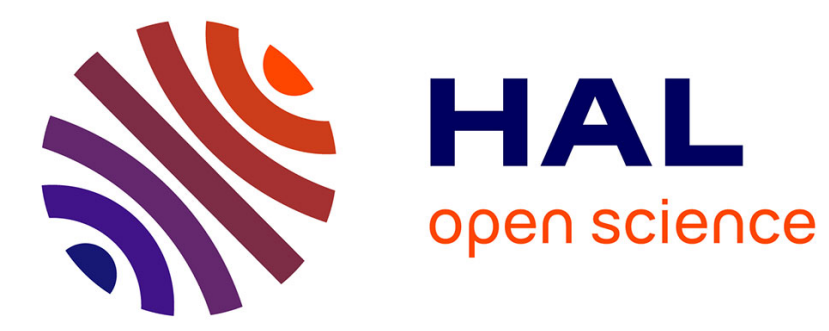

\title{
Green roofs against pollution and climate change. A review
}

\author{
Yanling Li, Roger Babcock
}

\section{To cite this version:}

Yanling Li, Roger Babcock. Green roofs against pollution and climate change. A review. Agronomy for Sustainable Development, 2014, 34 (4), pp.695-705. 10.1007/s13593-014-0230-9 . hal-01234839

\section{HAL Id: hal-01234839 \\ https://hal.science/hal-01234839}

Submitted on 27 Nov 2015

HAL is a multi-disciplinary open access archive for the deposit and dissemination of scientific research documents, whether they are published or not. The documents may come from teaching and research institutions in France or abroad, or from public or private research centers.
L'archive ouverte pluridisciplinaire HAL, est destinée au dépôt et à la diffusion de documents scientifiques de niveau recherche, publiés ou non, émanant des établissements d'enseignement et de recherche français ou étrangers, des laboratoires publics ou privés. 


\title{
Green roofs against pollution and climate change. A review
}

\author{
Yanling Li • Roger W. Babcock Jr.
}

Accepted: 13 April 2014 / Published online: 27 May 2014

(C) INRA and Springer-Verlag France 2014

\begin{abstract}
Green roofs recover green spaces in urban areas and benefit the public, farmers, and wildlife by providing many environmental, ecological, and economic advantages. Green roofs reduce stormwater runoff, mitigate urban heat island effects, absorb dust and smog, sequester carbon dioxide, produce oxygen, create space for food production, and provide natural habitat for animals and plants. Here, we studied the environmental impact of green roofs in terms of runoff quality and greenhouse gas $\mathrm{CO}_{2}$ sequestration. We screened more than 650 scientific papers and we reviewed detailed findings from 52 publications. There are two major points: (1) Concerning pollution, the concentrations of minor pollutants, such as heavy metals, biochemical oxygen demand (BOD), total suspended solids (TSS), and turbidity, are small and thus do not pose an immediate threat to the environment. However, the concentrations of major pollutants, such as nitrogen of $0.49-9.01 \mathrm{mg} / \mathrm{l}$ and phosphorus of $0.04-25 \mathrm{mg} / \mathrm{l}$, vary highly for different green roofs and can adversely affect runoff quality. Nutrient leaching may be controllable through proper mitigation measures including better design and system management which require further research. According to both laboratory experiments and field monitoring data, the main factors affecting runoff quality are precipitation properties, growth media composition and depth, plant species, and maintenance protocols. Research gaps exist in quantifying how these factors affect leachate pollutant load. Systematic studies are needed for improving green roof designs to reduce adverse impacts. (2) Concerning $\mathrm{CO}_{2}$ sequestration, studies reveal that green roofs directly sequester substantial amounts of carbon in plants and soils through photosynthesis. Green roofs reduce ambient $\mathrm{CO}_{2}$ concentrations in the vicinities. Green roofs also indirectly reduce $\mathrm{CO}_{2}$ releases from power plants and furnaces
\end{abstract}

Y. Li $\cdot$ R. W. Babcock Jr. $(\triangle)$

Department of Civil and Environmental Engineering, University of Hawaii at Mānoa, 2540 Dole Street, Holmes Hall 383, Honolulu, HI 96822, USA

e-mail: rbabcock@Hawaii.edu by reducing demand for heating and cooling, suggesting longterm economic and environmental benefits of green roofs.

Keywords Green roof $\cdot$ Nitrogen $\cdot$ Phosphorus $\cdot$ Runoff quality $\cdot \mathrm{CO}_{2}$ sequestration $\cdot$ Pollution mitigation

Contents

1. Introduction . . . . . . . . . . . . . . . 1

2. Common pollutants in green roof runoff. . . . . . . 2

2.1. Nitrogen . . . . . . . . . . . . . . . . . 2

2.2. Phosphorus ....................4 4

2.3. Heavy metals, BOD, and TSS ......... 4

2.4. Summary. . . . . . . . . . . . . . . . . 5

3. Factors affecting runoff quality and mitigation measures. . . . . . . . . . . . . . . . . . . . . . ...5

3.1. Properties of precipitation, antecedent dry days, and seasonal variation $\ldots \ldots \ldots \ldots \ldots \ldots \ldots \ldots$

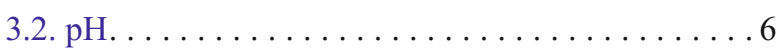

3.3. Growth media ..................6 6

3.4. Plant species . . . . . . . . . . . . . . . . . 7

3.5. Fertilization. . . . . . . . . . . . . . . . 7

3.6. Summary of affecting factors and research gaps ...8

4. Contribution of green roofs to $\mathrm{CO}_{2}$ sequestration ... . 8

4.1. Climate change, $\mathrm{CO}_{2}$ sequestration, and green

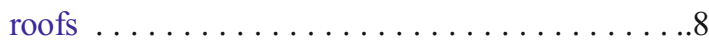

4.2. $\mathrm{CO}_{2}$ sequestration study findings of green roofs $\ldots .8$

5. Conclusions . . . . . . . . . . . . . . . . . .9

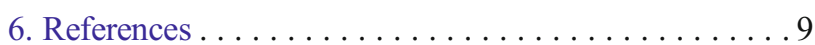

\section{Introduction}

Green roofs could provide economic benefits to the general public and to farmers. They are effective at saving building energy (Saadatian et al. 2013; He and Jim 2010) by reducing 
solar heating of interior spaces via shading, insulation, and evapotranspiration (Ouldboukhitine et al. 2012; Jim and Tsang 2011; Wong et al. 2003). Study results from Chan and Chow (2013) showed that a typical building with a $40 \mathrm{~cm}$ green roof could directly reduce the year-round air conditioning energy consumption by 2.4 to $10 \%$. Green roofs could contribute to agricultural food production by providing vegetated space on normally unused rooftops. Though many green roof agricultural products have been produced on intensive green roofs with substrate depths greater than $15 \mathrm{~cm}$, a recent study conducted in Michigan by Whittinghill et al. (2013) has shown that it is possible to produce common vegetables and herbs on extensive green roofs (depth $10.5 \mathrm{~cm}$ ) with minimal fertilizer inputs. The authors believed that a more sophisticated management strategy could enable production of yields similar to those produced in-ground. Green roofs (see Fig. 1 for sample) also provide numerous environmental benefits including reducing stormwater runoff, improving air quality, and absorbing noise. These benefits have led to a rapid growth in green roof installations and research in the past two decades.

Up to the present, there have been more than 650 papers published involving green roofs (Web of Science). Approximately 400 of the articles describe research-based activities in a diversity of fields including engineering, environmental science, agronomy, architecture, and ecology. We have grouped the research articles into ten topic areas including thermal effects, runoff quality, hydrology, ecology, plants, growth media, air pollution, noise reduction, and reviews (Fig. 2). Of these topics, green roof stormwater runoff quality is the second most highly investigated (62 papers, $16 \%$ ). Air pollution is a relative new topic area (15 papers, $4 \%$ ), which includes findings on carbon dioxide $\left(\mathrm{CO}_{2}\right)$ sequestration.

In 2010, a review of green roof runoff water quantity and quality was published in Ecological Engineering (Berndtsson 2010). The review covered 47 research papers (1998-2009)

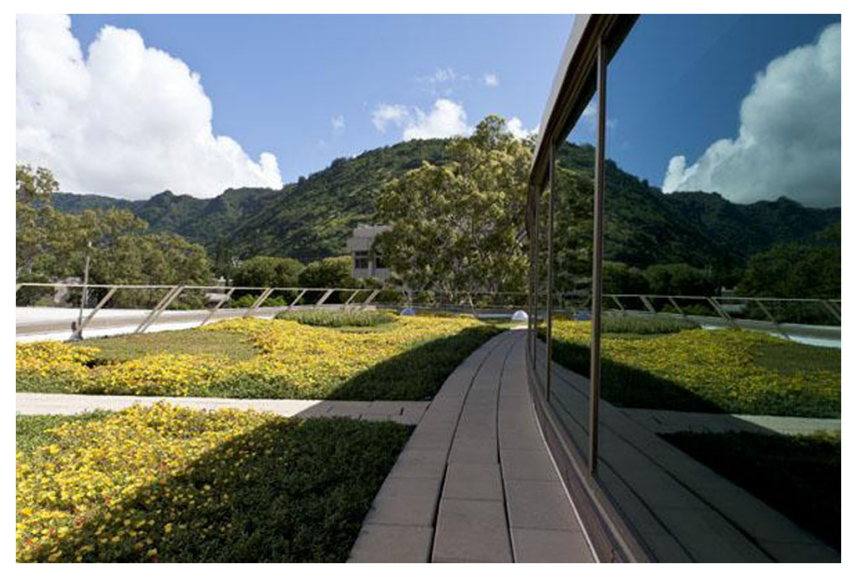

Fig. 1 A 2,500 square foot green roof at the LEED Platinum Laboratory, the Center for Microbial Oceanography: Research and Education, CMORE Hale, University of Hawaii at Mānoa on green roof runoff water quantity and quality. Major research findings and affecting factors were summarized in general terms. More than 350 papers have been published since this review, and approximately 1 million $\mathrm{m}^{2}$ of roofs have been greened every year in North America and 11 million $\mathrm{m}^{2}$ in Germany per world green infrastructure network statistics (World Green Infrastructure Network 2009). Both green roof technology and the number of applications have been developing rapidly in the past 4 years making it important to synthesize and analyze the past and up-to-date research data on runoff quality control measures in green roof designs to determine research gaps. In addition, it is important to provide a first review of green roof contribution to greenhouse gas $\mathrm{CO}_{2}$ reduction.

The surface runoff and leachate underflow from a green roof contain various constituents. Theoretically, a green roof is a vegetated buffer and thus should adsorb pollutant. However, a green roof can potentially release pollutants from the growth media, aged vegetation tissues, or fertilizer. Thus, the runoff may contain various metals, organics, and inorganic ions. Differences in water quality leaving green roofs can be caused by many factors including design characteristics such as media type, vegetation type, fertilization rate, the quality of source water (irrigation and precipitation), its exposure to contaminants during its movement on the surfaces, in the growth media (engineered soil), and in the water drainage conduit. Precipitation may contain nitrates and metals, depending on local pollution sources and prevailing winds. These affecting factors and their potential mitigation measures are discussed in this paper.

Commonly known for energy savings in heating and cooling, and heat island effect mitigation, a green roof's ability to sequester $\mathrm{CO}_{2}$ has been less researched among the many environmental benefits. Carbon is not only absorbed directly by the plants and growth media in green roofs through biological processes but also reduced indirectly in emissions from power plants and furnaces due to realized energy savings in heating and cooling. To investigate the $\mathrm{CO}_{2}$ sequestration issue, this paper reviewed publications from a variety of fields, such as crop and soil science, civil and environmental engineering, mechanical and materials engineering, and architecture. The research findings and the importance of reducing $\mathrm{CO}_{2}$ are presented.

\section{Common pollutants in green roof runoff}

\subsection{Nitrogen}

The release of nitrogen into freshwater causes eutrophication which depletes shallow water oxygen and potentially reduces specific fish and other biotic populations. Nearly all the studies on green roof runoff quality detected nitrogen in the runoff, 
Fig. 2 Published research papers on green roofs in the last two decades show a rapid growth trend

\section{Publication}

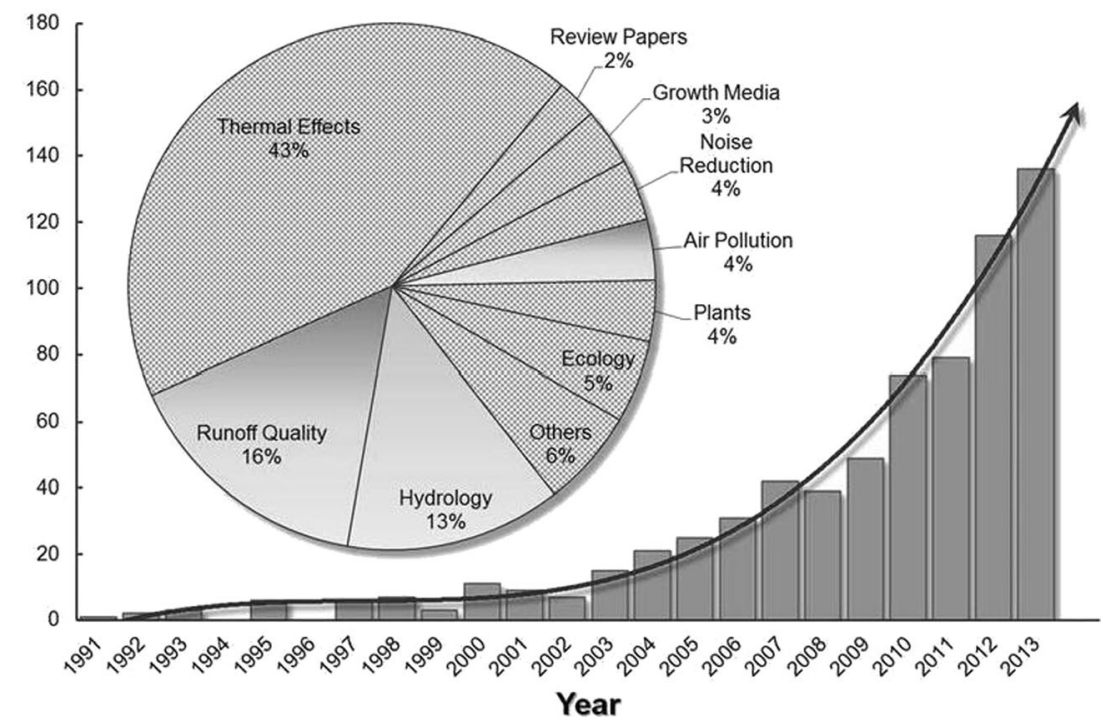

but the results vary significantly. Teemusk and Mander (2011) found that the concentrations of various nitrogen forms were not high in green roof runoff $\left(\mathrm{NH}_{4}-\mathrm{N} 0.38 \mathrm{mg} / \mathrm{l} ; \mathrm{NO}_{3}-\mathrm{N}\right.$ $0.46 \mathrm{mg} / \mathrm{l})$. Aitkenhead-Peterson et al. (2011) reported a larger amount of nitrate nitrogen $\left(\mathrm{NO}_{3}-\mathrm{N} 2.1 \mathrm{mg} / \mathrm{l}\right)$ in the runoff than in precipitation $(0.2 \mathrm{mg} / \mathrm{l})$. Gregoire and Clausen (2011) found the concentrations of total nitrogen (TN $4.27 \mathrm{mg} / \mathrm{l}$ ) in green roof runoff were similar to precipitation $(6.29 \mathrm{mg} / \mathrm{l})$, and were significantly lower than control watershed runoff concentrations $(10.82 \mathrm{mg} / \mathrm{l})$, suggesting that the green roof acted as a sink. Berndtsson et al. (2009) also found that both extensive (3-cm depth) and intensive (40-cm depth) green roofs were a sink for nitrogen (less in runoff than in precipitation). Other studies (Aitkenhead-Peterson et al. 2011) reported substantial release of nitrate nitrogen from green roofs (up to $6.6 \mathrm{mg} / \mathrm{l}$ in some rain events). Average nitrogen concentrations in various forms in the runoff from nine green roof studies are summarized in Figs. 3, 4, and 5. In most cases,

\section{$\log$ NH4-N (mg/l)}

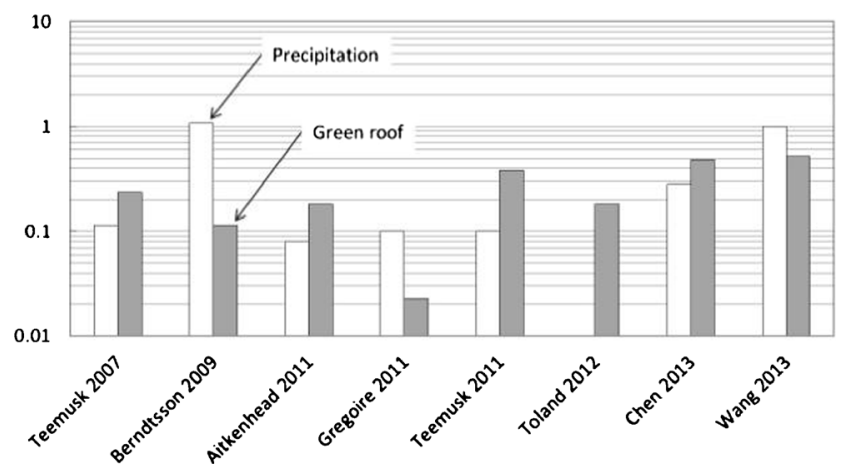

Fig. 3 Average concentrations of ammonium nitrogen in precipitation (white) and green roof runoff (gray). Concentrations of ammonium nitrogen in green roof runoff exceeded that in precipitation in five out of eight studies nitrogen concentrations were below the US Environmental Protection Agency (EPA)'s recommended standard of $10 \mathrm{mg} / 1$ in freshwater; while this is encouraging, it is not useful for the design of a green roof or the prediction of anticipated performance for a given design.

The concentration of nitrogen in runoff can be linked to the properties of green roof elements and to maintenance practices. Nitrogen enters the system through bacterial activity, fertilization, and from precipitation (deposition of fossil fuel combustion products). Most nitrogen shows up in the runoff in the forms of ammonium nitrogen and nitrate nitrogen. These inorganic forms of nitrogen are soluble and mobile in water. The runoff may also contain substantial amounts of organic nitrogen (Gregoire and Clausen 2011); however, most studies reported only ammonium and nitrate or simply total nitrogen concentrations. Ammonium nitrogen is positively charged and tends to be attracted to and adsorbed by soil particles. Nitrate nitrogen is negatively charged and is repelled

\section{$\log \mathrm{NO}_{3}-\mathrm{N}(\mathrm{mg} / \mathrm{l})$}

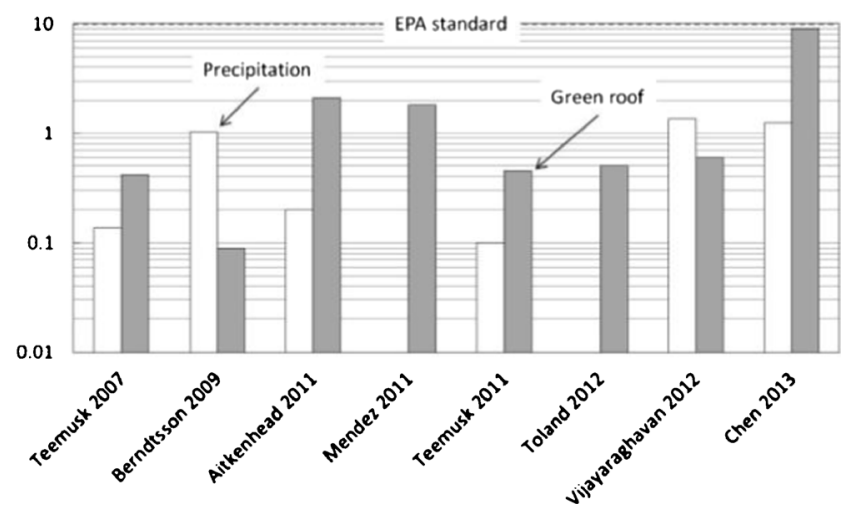

Fig. 4 Average concentrations of nitrate nitrogen in precipitation (white) and green roof runoff (gray). Concentrations of nitrate nitrogen in green roof runoff exceeded that in precipitation in six out of eight studies 


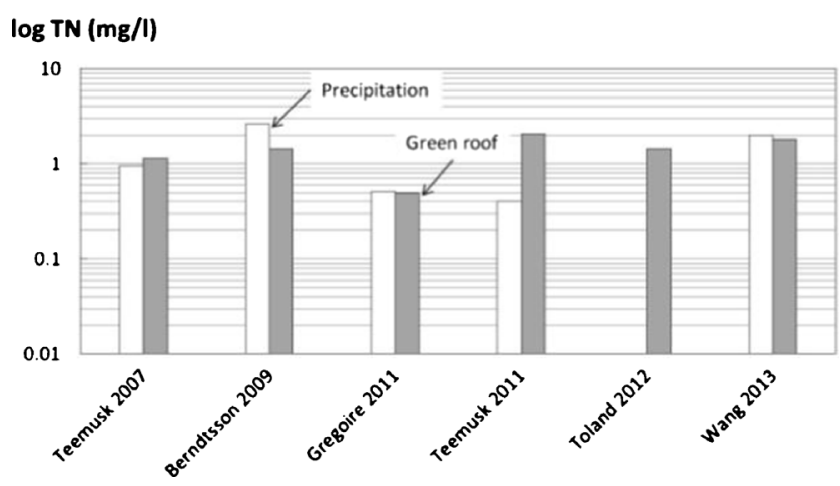

Fig. 5 Average concentrations of total nitrogen in precipitation (white) and green roof runoff (gray). Concentrations of total nitrogen in green roof runoff exceeded that in precipitation in three out of six studies

by negatively charged soil particles. Nitrate nitrogen is more subject to leaching than ammonium nitrogen during moderate rain events. But during heavy precipitation events and melting of snow, ammonium can exceed nitrate in green roof runoff (Teemusk and Mander 2007).

\subsection{Phosphorus}

Phosphorus releases to surface water also cause eutrophication and are common in green roof runoff. Phosphorus concentrations varied dramatically in different studies, from 0.006 (Teemusk and Mander 2011) to $66.0 \mathrm{mg} / \mathrm{l}$ in one case (Vijayaraghavan et al. 2012). Measurements by Toland et al. (2012) indicated that concentrations of total phosphorus (TP) in most green roof runoff $(0.17 \mathrm{mg} / \mathrm{l}$ without compost to $2.03 \mathrm{mg} / \mathrm{l}$ with compost) were much greater than that in runoff from conventional roofs $(0.03$ to $0.04 \mathrm{mg} / \mathrm{l})$ and in stream water $(0.11$ to $0.28 \mathrm{mg} / \mathrm{l})$. Aitkenhead-Peterson et al. (2011) also reported a much greater amount of phosphate phosphorus $\left(\mathrm{PO}_{4}-\mathrm{P} 3.5 \mathrm{mg} / \mathrm{l}\right)$ in green roof runoff than in precipitation $(0.03 \mathrm{mg} / \mathrm{l})$. While Gregoire and Clausen (2011) found the concentrations of phosphorus (TP $0.043 \mathrm{mg} / \mathrm{l} ; \mathrm{PO}_{4}-\mathrm{P}$ $0.025 \mathrm{mg} / \mathrm{l})$ in green roof runoff were not significantly different from precipitation (TP $0.007 \mathrm{mg} / \mathrm{l} ; \mathrm{PO}_{4}-\mathrm{P} 0.004 \mathrm{mg} / \mathrm{l}$ ) and were significantly lower than control watershed runoff concentrations (TP $0.197 \mathrm{mg} / \mathrm{l} ; \mathrm{PO}_{4}-\mathrm{P} 0.165 \mathrm{mg} / \mathrm{l}$ ), suggesting that the green roof was effective in reducing phosphorus loading to receiving waters. The average concentrations of phosphorus found in green roof runoff reported from eight studies are summarized in Figs. 6 and 7. Most of the measured concentrations of phosphate phosphorus in runoff (even in precipitation event) were above EPA's recommended freshwater standard of $0.05 \mathrm{mg} / \mathrm{l}$. Clearly, it is imperative to study the mechanisms of phosphorus leaching and to develop mitigation measures.

Current research on phosphorus leaching from green roofs is limited. Precipitation usually contains very low total phosphorus concentrations of 0.015 to $0.040 \mathrm{mg} / 1$ (Berndtsson $\log \mathrm{PO}_{4}-\mathrm{P}(\mathrm{mg} / \mathrm{I})$

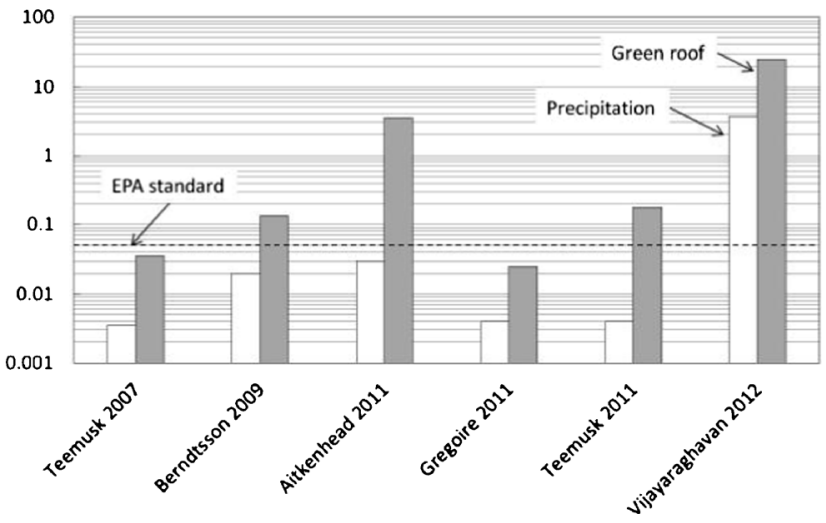

Fig. 6 Average concentrations of phosphate phosphorus in precipitation (white) and green roof runoff (gray). Concentrations of phosphate phosphorus in green roof runoff exceeded that in precipitation in all six studies

et al. 2009; Chen 2013; Gregoire and Clausen 2011; Teemusk and Mander 2007, 2011), thus phosphorus contamination in runoff (commonly $\mathrm{PO}_{4}-\mathrm{P}$ ) generally originated from fertilizers and minerals in the growth media. Within the green roof growth media, phosphorus exists in multiple organic and inorganic forms, and phosphorus leaching is controlled both by solubility and sorption/desorption reactions.

\subsection{Heavy metals, BOD, and TSS}

Green roof runoff was found to contain traces of heavy metals including $\mathrm{Fe}, \mathrm{Cu}, \mathrm{Al}$, and $\mathrm{Zn}$ (Berndtsson 2010). Vijayaraghavan et al. (2012) showed that many other species were also present including $\mathrm{Na}, \mathrm{K}, \mathrm{Ca}, \mathrm{Mg}, \mathrm{S}$, and $\mathrm{Cl}$, but the amounts were insignificant based on EPA standards for freshwater quality. Based upon a 22- to 32-month field study, Alsup et al. (2013) reported that generally green roof systems were not a source of metals. Gnecco et al. (2013) reported that zinc and mainly copper were retained in green roofs. Ye et al. (2013) found green roof plants assimilated substantial amounts of heavy metals in the roots and aboveground plant tissues from the growth media made from recycled bricks.

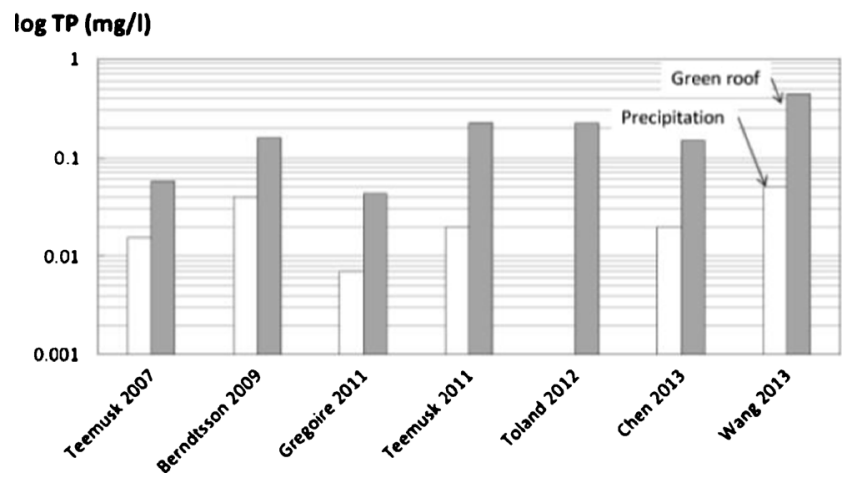

Fig. 7 Average concentrations of total phosphorus in precipitation (white) and green roof runoff (gray). Concentrations of total phosphorus in green roof runoff exceeded that in precipitation in all seven studies 
However, most of the studies were based on individual events rather than long-term samplings, drainage conveyance/piping materials, local air quality, and other factors could supply heavy metals in the runoff (Rowe 2011). For example, pine bark amendments were observed to cause elevated $\mathrm{Cu}$ in runoff (Alsup et al. 2013), rooftop catchment areas containing exposed metal surfaces released heavy metals (Lye 2009), and zinc-coated roofing materials were a source of zinc in runoff (Heijerick et al. 2002). But, in general, green roofs are a sink for heavy metals. Some plants (e.g., grass) absorb and fix these heavy metals in their tissues. And Gregoire and Clausen (2011) found that repeated wetting and drying cycles (which is especially the case in green roof environment) and the formation of chelates with organic materials stabilized heavy metals in the media.

Biochemical oxygen demand (BOD) in green roof runoff describes organic compounds originating from the decomposition of plant remnants. High concentrations of BOD in surface runoff will occur from lawns with animal excrement or after trimming. BOD does not seem to be an important contaminant in green roof runoff because most green roofs are not designed to accommodate large animals, and do not require trimming, and extensive growth is also discouraged on the roof environment. Teemusk and Mander (2011) studied several light-weight, aggregate-based green roofs at many different locations and found $\mathrm{BOD}_{7}$ ranged from 1.1 to $4.8 \mathrm{mg} / \mathrm{l}$ in the green roof runoff, similar to the 1.4 to $4.5 \mathrm{mg} / \mathrm{l}$ in precipitation.

Total suspended solids (TSS) and turbidity were occasionally reported in green roof studies. Al-Yaseri et al. (2013) showed a strong positive correlation between TSS and turbidity. The authors suggested that turbidity be used as a fast and effective substitute for TSS in green roof runoff. New green roofs tend to release fine particles, but as roots become established and organic content increases, the release slows dramatically. Chen (2013) reported a ten times higher TSS concentration from a green roof than from a bare roof in a study in Taiwan, and the author noted that low precipitation rates generally trapped pollutants, while high-intensity precipitation reduced pollutant retention. In Taiwan, intensive precipitation events are frequent, especially during the typhoon season. In such places, the design must consider potential erosion issues and have good maintenance practices. However, in general, TSS and turbidity do not appear to be an issue in green roof runoff, especially when modern green roofs are lined with geotextile to contain fine particles in the growth media. For example, Morgan et al. $(2011,2013)$ studied TSS and turbidity in the runoff from four growth media (arkalyte, bottom ash, haydite, and lava) in planted and unplanted plots of over 6 months and reported that, in the first watering event, TSS was reduced by 54 to $71 \%$ and the turbidity was reduced by 27 to $71 \%$.

\subsection{Summary}

The reviewed literatures indicate that the concentrations of minor pollutants including heavy metals, BOD, TSS, and turbidity are small and do not pose a threat to the environment. However, long-term systematic sampling is needed to fully evaluate minor pollutant leaching. Nearly all published papers reported nitrogen and phosphorus in green roof runoff. Ammonium nitrogen is higher in runoff than precipitation for five of eight studies, nitrate is higher in six of eight studies, total nitrogen is higher in three of six studies, and phosphate and total phosphorus are higher in all nine studies. Most of the time nitrogen was below the freshwater standard, but phosphorus often exceeded it. Additional research is necessary to determine why nitrogen is sometimes higher and sometimes lower than in precipitation, and why phosphorus is always higher in runoff than in precipitation. These questions pointed toward the investigation of affecting factors and potential mitigation measures.

\section{Factors affecting runoff quality and mitigation measures}

\subsection{Properties of precipitation, antecedent dry days, and seasonal variation}

Precipitation volume is one the most important factors affecting nitrogen and phosphorus leaching. Nitrogen is highly mobile in water. Berndtsson (2010) and Teemusk and Mander (2011) found that more nitrogen is washed out during heavy precipitation than during moderate events. Phosphorus leaching is also greater during heavy precipitation (Teemusk and Mander 2011). Consequently, to minimize nutrient leaching, it is advisable that irrigation be curtailed prior to precipitation events whenever possible and that fertilization be avoided during the wet season.

The dynamics of precipitation also plays an important role. Vijayaraghavan et al. (2012) found that concentrations of most chemical constituents in green roof runoff were highest during the beginning of the rain season and decreased in the following precipitation events. Berndtsson et al. (2008) found that concentrations of chemical constituents were higher in first-flush runoff samples than in later samples. These findings suggested that the pollutants could be contained or reduced by installing a first-flush diversion system to capture, retain, and possibly recycle the first-flush runoff. Designers may utilize these findings to decrease the possibility of green roof impacts on water quality.

Antecedent dry days affect runoff quality. The roofs acted as a sink for nitrogen, phosphorus, zinc, and copper for small rain events following the dry period. Otherwise the roofs may become a source of pollutants, especially phosphorus (Seidl et al. 2013). Mendez et al. (2011) monitored three rain events 
and found that some nitrate concentrations in the first-flush increased as the number of antecedent dry days increased. This finding indicated that dry deposition from ambient air contribute to nitrate and phosphorus levels in green roof runoff and also suggested that a well-designed green roof could be used as a best management practice (BMP) to remove pollutants from air (Yang et al. 2008). For instance, Sempel et al. (2013) discovered that extensive green roofs with sedum removed up to $33.4 \%$ of the fine dust particles from the wind below a speed of $2 \mathrm{~m} / \mathrm{s}$.

The amount of pollutants discharged varies with the season. This occurs because the water retention capacity of a green roof varies and so does its capacity to retain contaminants. Schroll et al. (2011) found that vegetation had significant influence on stormwater retention during summer than winter. Therefore, the seasonal variation of hydrologic properties may, in turn, affect the amount of pollutants discharged into the runoff. This finding suggested that runoff quality from a green roof was affected by its hydrologic properties, since water flow was the carrier of pollutants. Thus, in modeling studies, water quantity and quality should be coupled.

\section{$3.2 \mathrm{pH}$}

Green roofs generally neutralize acid rain and increase $\mathrm{pH}$, which in turn affects the chemistry in a green roof. Fig. 8 shows that green roofs increased the $\mathrm{pH}$ of precipitation to levels within EPA's recommended freshwater standard of 6.5 to 9 (Aitkenhead-Peterson et al. 2011; Berndtsson et al. 2009; Bliss et al. 2009; Chen 2013; Mendez et al. 2011; Teemusk and Mander 2007, 2011; Vijayaraghavan et al. 2012). The $\mathrm{pH}$ of precipitation is usually lower than that of green roof growth media and can be as low as 3 in some urban areas. Acid deposition is neutralized by the vegetation and growth media, indicating that a green roof can be a good BMP for mitigating acid rain runoff in urban areas. Green roofs could protect freshwater and terrestrial ecosystems, historical buildings, monuments, and building materials.

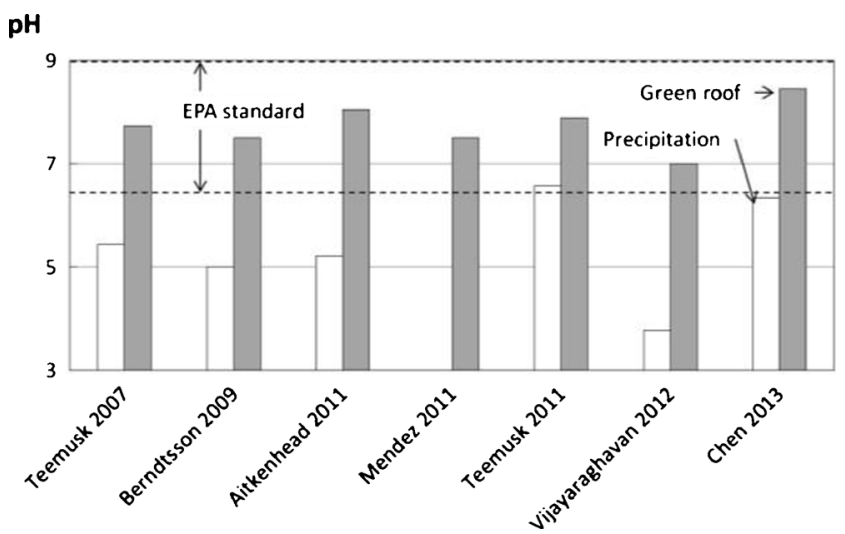

Fig. 8 Reported $\mathrm{pH}$ in precipitation (white) and green roof runoff (gray) from seven studies. Green roofs neutralized acid rain and increased $\mathrm{pH}$
Because $\mathrm{pH}$ affects chemical processes both in plants and the growth media, the $\mathrm{pH}$ of precipitation can affect the nitrogen and phosphorus content in the runoff. $\mathrm{pH}$ may also affect nitrite and nitrate nitrogen leaching by affecting soil particle surface charge. Soil particle surfaces become more negatively charged as the $\mathrm{pH}$ increases and therefore more repellent to negatively charged nitrogen species. For phosphorus, the $\mathrm{pH}$ effect depends on the ion content of the soil. Phosphorus compounds tends to be fixed by $\mathrm{Al}$ and $\mathrm{Fe}$ ions at $\mathrm{pH}$ less than 5 and by $\mathrm{Ca}$ ions at $\mathrm{pH}$ greater than 8 . Phosphate phosphorus has the strongest soil particle binding capacity at pH 6 to 7, and in this range, phosphate phosphorus is mostly adsorbed on soil particles. Because different plants have different preferences for $\mathrm{pH}$, it could be a complex task for designers to coordinate growth media amendments, plant types, local precipitation $\mathrm{pH}$ properties, and runoff quality requirements.

\subsection{Growth media}

Physical properties and chemical constituents vary in green roof growth media. There are many types of media (Molineux et al. 2009) including crushed red brick (the UK industry standard substrate), pellets made from clay and sewage sludge, fly ash, paper ash (from recycled newspapers), and carbonated limestone. Vijayaraghavan et al. (2012) found that the concentration of chemical components in the green roof runoff strongly depended on the nature of growth media used. Different growth media will have different tendencies to retain or release various constituents due to chemical and physical properties. For example, sand media is subject to substantially greater loss of ammonium than clay media due to the difference in particle surface area. Weathered soils can have significant positive charges if the $\mathrm{pH}$ is below the point of zero net charge. This positive charge will hold anions such as nitrite and nitrate. Organic content, carbon content, and microorganisms also affect nutrient leaching. Nagase and Dunnett (2011) recommended that the addition of $10 \%$ organic matter (by volume) as optimal for extensive green roofs in terms of plant growth, but Teemusk and Mander (2007) stated that compost in the substrate caused high concentrations of nitrogen in the green roof runoff. Toland et al. (2012) found total nitrogen in runoff from extensive green roofs fertilized with $15 \%$ compost by volume was much higher (1.88 to $1.71 \mathrm{mg} / \mathrm{l})$ than from conventional roofs $(0.41$ to $0.68 \mathrm{mg} / \mathrm{l})$. Total phosphorus (1.57 to $1.82 \mathrm{mg} / \mathrm{l})$ was also much higher than conventional roofs $(0.01$ to $0.02 \mathrm{mg} / \mathrm{l})$. Growth media that contains heavy metals may produce runoff containing these metals. Alsup et al. (2011) found that Arkalyte (an expanded clay) when mixed with pine bark, leached $\mathrm{Cd}, \mathrm{Fe}$, $\mathrm{Ni}, \mathrm{Pb}$, and $\mathrm{Zn}$. Other materials used in green roofs, such as bitumen, attracts dust and other contaminants that contain phosphorus, causing an increase in total phosphorus 
concentration. Teemusk and Mander (2007) demonstrated that total phosphorus concentrations were higher in the bituminous roof runoff and that some light weight aggregates contributed to a high concentration of phosphorus in leachate.

A soil amendment that is able to retain nutrients was suggested to prevent water-soluble nutrients from leaching into runoff. Beck et al. (2011) used simulated precipitation events and found that green roof media containing $7 \%$ biochar (produced by pyrolysis of biomass in a low-oxygen, hightemperature environment) showed increased water retention $(4.4 \%)$ and significant reduction in discharge of nitrate or total nitrogen (79-97\%), phosphate (38-48\%), total phosphorus (20-52\%), inorganic carbon (4-12\%), and organic carbon (67-72\%). However, there are many types of biochars and the properties vary significantly such that some biochar may adversely restrict plant growth by withholding the release of nutrients. Further investigations are required on this subject.

In addition to the nature of the growth media, the media depth may profoundly affect the leaching process. Wang et al. (2013) conducted a field study to evaluate pollutant concentrations in green roof runoff. Results revealed that the concentration of pollutants in runoff strongly depended on the depth of growth media. Cahn et al. (1993) investigated the soil $\mathrm{NO}_{3}$ concentration of various treatments (e.g., manure and urea) versus soil depth in agricultural fields at various time intervals during the growth season and found that the $\mathrm{NO}_{3}$ distribution profile changed with time and that downward movement of $\mathrm{NO}_{3}$ was accelerated by precipitation. In green roof systems, greater media depth could retain nutrients for longer durations and increase the chance for them to be consumed. To investigate this subject, research work similar to Cahn's could be performed in green roof studies to investigate the relationships among precipitation/irrigation, amount/timing of nutrient application, and media depths to facilitate creation of green roof design that minimize leaching.

\subsection{Plant species}

The species of plant cultivated on a green roof can also impact runoff water quality. Beck et al (2011) found that sedum species released much less nutrients than ryegrass. Aitkenhead-Peterson et al. (2011) compared three types of plants in the same media and found differences in nitrogen and phosphorus concentrations in runoff (Fig. 9). Ammonia was slightly higher than in precipitation but lower than in the unplanted roof (growth medium only) runoff. Nitrate was always significantly higher in green roof runoff compared to precipitation, but for two species, it was much lower than the unplanted roof; with one case (Sedum kamtschaticum), the nitrate in runoff was greater than the unplanted roof.

Plants do not always perform consistently. Their growth is determined by the environment. For example, Rowe et al. (2012) tested 20 species in various media depths and found

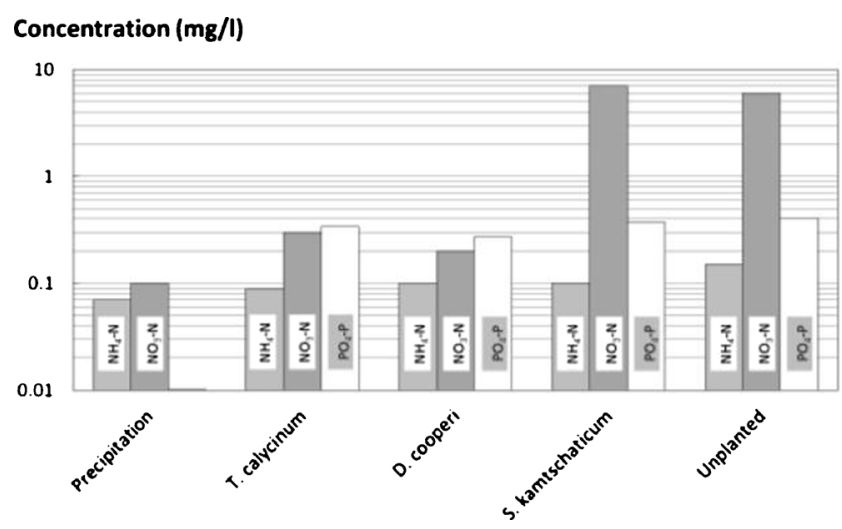

Fig. 9 Concentration of various compounds in runoff from different plants and bare growth media, regenerated from Aitkenhead-Peterson et al. (2011)

that growth medium depth influenced the moisture content, plant growth, and biodiversity and, in turn, influenced the performance of the plants and the overall performance of the green roof. Plant species need to be selected in a way that is suitable for both the green roof environment and for runoff quality criteria. Green roofs with diverse plant types consume more nitrogen than monocultures (Cook-Patton and Bauerle 2012). Because nutrients are used more efficiently in diverse green roof plant communities, the use of fertilizer and potential leaching from green roofs could be reduced (Berndtsson 2010; Oberndorfer et al. 2007). In a review paper, Dvorak and Volder (2010) recommended the use of various plant species such as succulent and herbaceous perennials for different green roof conditions and configurations. Song et al. (2013) successfully experimented with a constructed wetland as a green roof system. Future studies may include development of a comprehensive plant database by investigating the requirements of different species with respect to nutrients, media depths, and irrigation as well as potentials of pollutant leaching.

\subsection{Fertilization}

There is a direct link between the release of nutrients from green roofs and the application of fertilizers (Berndtsson et al. 2006; Berndtsson et al. 2009; Bliss et al. 2009; Emilsson et al. 2007; Rowe 2011; Teemusk and Mander 2007). Greater nitrate nitrogen concentrations were usually observed in the earlier sampling events following construction. Use of controlled release fertilizer (CRF) instead of conventional fertilizers could mitigate this effect. Also, fertilization should be avoided during the wet season and before possible precipitations. In general, knowledge of specific plant nutrient requirements and fertilization synchrony with growth stages of the plant is an important approach to minimize nutrient loss. For example, most plants require increased nitrogen during rapid growth periods, while phosphorus is required during plant establishment periods. A successful case is the study from Chen et al. (2011) who 
applied precise irrigation and synchronized nitrogen supplies to crops to reduce nutrient loss to nearly zero in comparison to $127 \mathrm{~kg} \mathrm{~N} / \mathrm{ha}$ loss in typical farming practice.

\subsection{Summary of affecting factors and research gaps}

From the reviewed studies, precipitation is one of the key affecting factors. Nutrient leaching during precipitation generally increases as precipitation amount increases, precipitation duration decreases, and as antecedent dry period increases. Nutrient leaching also varies with season due to plant growth status and varies among plant species due to biological characteristics. Two other dominant factors are properties of the growth media and management of fertilization.

Research gaps exist for each of these affecting factors. Leaching studies are underdeveloped in terms of utilizing hydrologic analysis to determine patterns and allow extrapolation to conditions different than the measured experiments. Research development in quantitative analysis and prediction is marginal. Chemical properties of growth media and amendments, such as biochar and their response to fertilization, are very limited in scope and lack in definitive findings that could be translated into design guidance. And currently, there is no green-roof-specific plant database comprehensive enough to assist green roof design. Due to complexity, almost all of the research work on green roof runoff water quality up to the present has consisted of observational studies. Unlike green roof hydrologic processes, for which many types of models in various scales have been developed, there is a lack of quantitative methodologies to predict potential green roof leaching problems. The only model found during the review was a GIS model (Zhen et al. 2006) that integrated conceptual BMP processes to simulate flow and pollutant transport in green roofs. It would be very beneficial to green roof design to develop quantitative methods or computer models for nutrient management. Potential research directions may include physical/chemical mechanisms of solute transport processes, nutrient response to precipitation dynamics, typical plant species nutrient demand at various growth stages, the performance of various growth media in retaining nutrients, and nutrient loss in response to chemical conditions such as $\mathrm{pH}$ and ion exchange capacity.

\section{Contribution of green roofs to $\mathrm{CO}_{2}$ sequestration}

\subsection{Climate change, $\mathrm{CO}_{2}$ sequestration, and green roofs}

The climate of Earth has changed in the past 1,300 years due to small variations in Earth's orbit that alter the amount of solar energy the planet receives. However, the current warming trend particularly concerned scientists because it is proceeding at an unprecedented rate and is suspected to be human-induced. The heat-trapping nature of $\mathrm{CO}_{2}$ gas has been known since the mid-19th century (USEPA 2013a). $\mathrm{CO}_{2}$ sequestration occurs through several natural processes, one of which is absorption by trees, plants, and crops during photosynthesis (USEPA 2013b), in which the carbon is stored in biomass (tree trunks, branches, foliage, and roots) and soils. The length of time that this carbon remains before decomposition has yet to be quantified for green roofs, but if net primary production exceeds decomposition, this man-made ecosystem could be a net carbon sink. Green roofs can also indirectly affect atmospheric $\mathrm{CO}_{2}$ concentrations because they are an excellent roof insulator that reduces heating and cooling needs and their associated $\mathrm{CO}_{2}$ releases from power plants and furnaces.

\section{2 $\mathrm{CO}_{2}$ sequestration study findings of green roofs}

Green roofs improve the energy performance of buildings. Sailor (2008) developed a physically based green roof energy balance model and integrated it into a building energy simulation model EnergyPlus. Using this model, the author simulated a $4,000 \mathrm{~m}^{2}$ two-storey office building in Chicago, IL and Houston, TX, with a 0.2 -m-thick green roof, vegetation leaf area index (LAI) of 2.0, and an irrigation rate of $1 \mathrm{~cm} /$ week during the summer (June-August) months. Simulation results showed approximately $2 \%$ of annual electricity savings in both locations and about $9 \%$ of annual gas savings in Chicago and $11 \%$ in Houston. Through varying the soil depth, LAI, and irrigation rate, the author found that thicker soil layer resulted in larger heating and cooling savings in both winter and summer; while higher vegetation density mainly resulted in larger electricity savings in summer; and increased irrigation rate slightly increased electricity savings.

Green roofs have large potential in sequestering $\mathrm{CO}_{2}$. Getter et al. (2009) conducted two sets of measurements to determine carbon sequestration performance of green roofs. First, 12 sedum-based extensive green roofs $(2.5$ to $12.7 \mathrm{~cm}$ depth) ranging from 1 to 6 years in age were sampled for aboveground biomass total carbon in 2006. Second, carbon analysis was performed by sampling aboveground biomass, belowground biomass (roots), and growth media carbon content over two growing seasons from June 2007 to October 2008. The first data set showed a high degree of variability of sequestered carbon from 73 to $276 \mathrm{~g} \mathrm{C} / \mathrm{m}^{2}$ among 12 green roofs, which were probably influenced by the age, media depth, fertilizer application, and irrigation. The second data set demonstrated a net change during two consecutive growing seasons. Results showed that aboveground biomass accumulated $168 \mathrm{~g} \mathrm{C} / \mathrm{m}^{2}$, roots accumulated $107 \mathrm{~g} \mathrm{C} / \mathrm{m}^{2}$, and media accumulated $100 \mathrm{~g} \mathrm{C} / \mathrm{m}^{2}$. The author concluded that green roofs provided an opportunity to sequester carbon and hypothesized that if all the roofs in Detroit metropolitan area were covered with similar green roofs, plants and media could 
sequester 55,252 tons of carbon, the amount equivalent to the emissions from approximately 10,000 mid-sized sport utility vehicle (SUV) or trucks.

The decrease of ambient $\mathrm{CO}_{2}$ concentration near green roofs is substantial. Li et al. (2010) studied the effect of green roofs on ambient $\mathrm{CO}_{2}$ concentration to assess the benefit of urban greening. $\mathrm{CO}_{2}$ concentrations above a $4 \mathrm{~m} \times 4 \mathrm{~m}$ green roof, and a bare control roof were monitored. Data showed that on a typical sunny day with light wind, the $\mathrm{CO}_{2}$ concentration above the green roof was $4.3 \mathrm{mg} / \mathrm{m}^{3}$ lower than at the control roof during the day time before 4PM and slightly higher during the night time. To further evaluate the effect of green roofs on ambient $\mathrm{CO}_{2}$ concentration, the author also measured the $\mathrm{CO}_{2}$ of the green roof in a chamber to construct an absorption/emission velocity curve. Using this $\mathrm{CO}_{2}$ absorption/emission velocity curve, the author modeled the green roof effects in an urban area with a species transport module from commercial computational fluid dynamics software. Simulation results showed that $\mathrm{CO}_{2}$ concentration around the green roof fell noticeably. Depending on the amount of wind facilitating the mixing, the reduction of $\mathrm{CO}_{2}$ concentration in the green roof vicinity reached up to $9.3 \%$.

The application of green roofs could yield a long term economic payback (Niu et al. 2010). Hong et al. (2012) and Kim et al. (2012) noted that the forest reduction rate in metropolitan areas was extremely high, and the area of forests was well below the World Health Organization's minimal standard. Hong considered green roofs as the optimum alternative to increase urban forests to control temperature and absorb $\mathrm{CO}_{2}$. The study used EnergyPlus that considered both economic and environmental effects to evaluate the benefits of adding green roofs to some educational facilities in Seoul, South Korea. There were 16 scenarios established by combining green roofs, external insulation, exterior blinds, double glazing, and LED light improvements. The study correlated energy consumption with $\mathrm{CO}_{2}$ equivalents. The rate of plant $\mathrm{CO}_{2}$ equivalent reduction was estimated by plant absorption rate. Then the results of the life cycle $\mathrm{CO}_{2}$ analyses with these various scenarios were converted to certified emission reductions (CERs) carbon credits and dollar values ( $\$ 4.49 /$ ton of $\mathrm{CO}_{2}$ equivalent). Life cycle cost analyses showed that when considering only the initial expense, the conventional roof system was superior to the green roof systems. However, when considering the environmental value, the results revealed that green roof system could induce up to $33.8 \%$ savings in terms of combined cost reduction and environmental values.

\section{Conclusions}

Green roof runoff water quality can be impacted by nitrogen and phosphorous leaching. Review results indicate that phosphorus discharges usually exceed EPA's freshwater standard, while most of the time nitrogen, although more leachable than phosphorus, is lower than the standard. Heavy metals, BOD, TSS, turbidity, and other minor pollutants are, at present, considered insignificant and as such to pose no risk to the environment; however, there is relatively little data and additional monitoring work seems prudent. The major factors that impact green roof runoff water quality are the growth media, vegetation species, precipitation properties, irrigation amount and timing, and plant fertilization practices. Most studies agree that fertilization and irrigation, which are controllable in contrast to weather conditions, should be managed scientifically, especially during the wet season. BMPs could be installed in series with green roofs to treat first flush waters. A tool $/$ model is needed to relate basis of design parameters of importance and precipitation/irrigation/fertilization properties to leachate pollutant load. Further research work in plant selection should include developing databases to help designers select green roof vegetation under a variety of growth media types, quality requirements, and meteorological conditions. Chemical/physical properties of growth media and their amendments need to be studied in order to provide high performance materials in terms of leaching reduction. Computer models of water/solute transport in soil systems need to be developed in concert with green roof leaching studies to investigate the complex relationship among precipitation/irrigation/fertilization events, and various green roof physical configurations.

Greenhouse gas $\mathrm{CO}_{2}$ sequestration by green roof systems was investigated and shown to be promising by researchers from various perspectives of crop and soil science, civil and environmental engineering, and architecture. These studies demonstrated the potential of green roofs for $\mathrm{CO}_{2}$ sequestration in the plants and soils if widely adopted, the noticeable concentration decrease near the green roof site, and the longterm economic benefits of adopting green roofs to reduce power consumption for heating and cooling. However, studies in this area are relatively new, and quantifications of $\mathrm{CO}_{2}$ sequestration potential appear to be preliminary. Research should continue to further evaluate the potential of greenhouse gas $\mathrm{CO}_{2}$ sequestration in green roof systems.

\section{References}

Aitkenhead-Peterson JA, Dvorak BD, Voider A, Stanley NC (2011) Chemistry of growth medium and leachate from green roof systems in south-central Texas. Urban Ecosys 14(1):17-33. doi:10.1007/ s11252-010-0137-4

Alsup SE, Ebbs SD, Battaglia LL, Retzlaff WA (2011) Heavy metals in leachate from simulated green roof systems. Ecological Engineering 37(11):1709-1717. doi:10.1016/j.ecoleng.2011.06.045

Alsup S, Ebbs S, Battaglia L, Retzlaff W (2013) Green roof systems as sources or sinks influencing heavy metal concentrations in runoff. $\mathrm{J}$ 
Environ Eng-Asce 139(4):502-508. doi:10.1061/(Asce)Ee.19437870.0000601

Al-Yaseri I, Morgan S, Retzlaff W (2013) Using turbidity to determine total suspended solids in storm-water runoff from green roofs. J Environ Eng-Asce 139(6):822-828. doi:10.1061/(Asce)Ee.19437870.0000685

Beck DA, Johnson GR, Spolek GA (2011) Amending greenroof soil with biochar to affect runoff water quantity and quality. Environ Pollut 159(8-9):2111-2118. doi:10.1016/j.envpol.2011.01.022

Berndtsson JC (2010) Green roof performance towards management of runoff water quantity and quality: a review. Ecol Eng 36(4):351360. doi:10.1016/j.ecoleng.2009.12.014

Berndtsson JC, Bengtsson L, Jinno K (2008) First flush effect from vegetated roofs during simulated rain events. Hydrol Res 39(3): 171-179. doi:10.2166/nh.2008.044

Berndtsson JC, Bengtsson L, Jinno K (2009) Runoff water quality from intensive and extensive vegetated roofs. Ecol Eng 35(3):369-380. doi:10.1016/j.ecoleng.2008.09.020

Berndtsson JC, Emilssonb T, Bengtsson L (2006) The influence of extensive vegetated roofs on runoff water quality. Sci Total Environ 355(1-3):48-63. doi:10.1016/j.scitotenv.2005.02.035

Bliss DJ, Neufeld RD, Ries RJ (2009) Storm water runoff mitigation using a green roof. Environ Eng Sci 26(2):407-417. doi:10.1089/ ees. 2007.0186

Cahn MD, Bouldin DR, Cravo MS, Bowen WT (1993) Cation and nitrate leaching in an oxisol of the Brazilian amazon. Agron J 85(2):334 340. doi:10.2134/agronj1993.00021962008500020032x

Chan ALS , Chow TT (2013) Energy and economic performance of green roof system under future climatic conditions in Hong Kong. Energ Buildings 64:182-198. doi:10.1016/j.enbuild.2013.05.015

Chen CF (2013) Performance evaluation and development strategies for green roofs in Taiwan: a review. Ecol Eng 52:51-58. doi:10.1016/j. ecoleng.2012.12.083

Chen XP, Cui ZL, Vitousek PM, Cassman KG, Matson PA, Bai JS, Meng QF, Hou P, Yue SC, Romheld V, Zhang FS (2011) Integrated soilcrop system management for food security. Proc Natl Acad Sci U S A 108(16):6399-6404. doi:10.1073/pnas.1101419108

Cook-Patton SC, Bauerle TL (2012) Potential benefits of plant diversity on vegetated roofs: a literature review. J Environ Manage 106:8592. doi:10.1016/j.jenvman.2012.04.003

Dvorak B, Volder A (2010) Green roof vegetation for North American ecoregions: a literature review. Landsc Urban Plan 96(4):197-213. doi:10.1016/j.landurbplan.2010.04.009

Emilsson TU, Berndtsson JC, Mattson JE, Rolf K (2007) Effect of using conventional and controlled release fertilizer on nutrient runoff from various vegetated roof systems. Ecol Eng 29:260-271. doi:10.1016/ j.ecoleng.2006.01.001

Getter KL, Rowe DB, Robertson GP, Cregg BM, Andresen JA (2009) Carbon sequestration potential of extensive green roofs. Environ Sci Technol 43(19):7564-7570. doi:10.1021/Es901539x

Gnecco I, Palla A, Lanza LG, La Barbera P (2013) The role of green roofs as a source/sink of pollutants in storm water outflows. Water Resour Manag 27(14):4715-4730. doi:10.1007/s11269-013-0414-0

Gregoire BG, Clausen JC (2011) Effect of a modular extensive green roof on stormwater runoff and water quality. Ecol Eng 37(6):963-969. doi:10.1016/j.ecoleng.2011.02.004

He HM, Jim CY (2010) Simulation of thermodynamic transmission in green roof ecosystem. Ecol Model 221(24):2949-2958. doi:10. 1016/j.ecolmodel2010.09.002

Heijerick DG, Janssen CR, Karlen C, Wallinder IO, Leygraf C (2002) Bioavailability of zinc in runoff water from roofing materials. Chemosphere 47(10):1073-1080. doi:10.1016/s0045-6535(02) 00014-0

Hong T, Kim J, Koo C (2012) LCC and $\mathrm{LCCO}_{2}$ analysis of green roofs in elementary schools with energy saving measures. Energy Buildings 45:229-239. doi:10.1016/j.enbuild.2011.11.006
Jim CY, Tsang SW (2011) Modeling the heat diffusion process in the abiotic layers of green roofs. Energ Buildings 43(6):1341-1350. doi: 10.1016/j.enbuild.2011.01.012

Kim J, Hong T, Koo CW (2012) Economic and environmental evaluation model for selecting the optimum design of green roof systems in elementary schools. Environ Sci Technol 46(15):8475-8483. doi: 10.1021/Es2043855

Li JF, Wai OWH, Li YS, Zhan JM, Ho YA, Li J, Lam E (2010) Effect of green roof on ambient CO2 concentration. Building Environ 45(12): 2644-2651. doi:10.1016/j.buildenv.2010.05.025

Lye DJ (2009) Rooftop runoff as a source of contamination: a review. Sci Total Environ 407(21):5429-5434. doi:10.1016/j.scitotenv.2009.07. 011

Mendez CB, Klenzendorf JB, Afshar BR, Simmons MT, Barrett ME, Kinney KA, Kirisits MJ (2011) The effect of roofing material on the quality of harvested rainwater. Water Res 45(5):2049-2059. doi:10. 1016/j.watres.2010.12.015

Molineux CJ, Fentiman CH, Gange AC (2009) Characterising alternative recycled waste materials for use as green roof growing media in the UK. Ecol Eng 35(10):1507-1513. doi:10.1016/j.ecoleng.2009.06. 010

Morgan S, Alyaseri I, Retzlaff W (2011) Suspended solids in and turbidity of runoff from green roofs. Int J Phytoremediat 13:179-193. doi: $10.1080 / 15226514.2011 .568547$

Morgan S, Celik S, Retzlaff W (2013) Green roof storm-water runoff quantity and quality. J Environ Eng-Asce 139(4):471-478. doi:10. 1061/(Asce)Ee.1943-7870.0000589

Nagase A, Dunnett N (2011) The relationship between percentage of organic matter in substrate and plant growth in extensive green roofs. Landsc Urban Plan 103(2):230-236. doi:10.1016/j. landurbplan.2011.07.012

Niu H, Clark C, Zhou J, Adriaens P (2010) Scaling of economic benefits from green roof implementation in Washington, DC. Environ Sci Technol 44(11):4302-4308. doi:10.1021/Es902456x

Oberndorfer E, Lundholm J, Bass B, Coffman RR, Doshi H, Dunnett N, Gaffin S, Kohler M, Liu KKY, Rowe B (2007) Green roofs as urban ecosystems: ecological structures, functions, and services. Bioscience 57:823-833. doi:10.1641/B571005

Ouldboukhitine SE, Belarbi R, Djedjig R (2012) Characterization of green roof components: measurements of thermal and hydrological properties. Build Environ 56:78-85. doi:10.1016/j.buildenv.2012. 02.024

Rowe DB (2011) Green roofs as a means of pollution abatement. Environ Pollut 159(8-9):2100-2110. doi:10.1016/j.envpol.2010.10.029

Rowe DB, Getter KL, Durhman AK (2012) Effect of green roof media depth on Crassulacean plant succession over seven years. Landsc Urban Plan 104(3-4):310-319. doi:10.1016/j.landurbplan.2011.11.010

Saadatian O, Sopian K, Salleh E, Lim CH, Riffat S, Saadatian E, Toudeshki A, Sulaiman MY (2013) A review of energy aspects of green roofs. Renew Sust Energ Rev 23:155-168. doi:10.1016/j.rser. 2013.02.022

Sailor DJ (2008) A green roof model for building energy simulation programs. Energ Buildings 40(8):1466-1478. doi:10.1016/j. enbuild.2008.02.001g

Schroll E, Lambrinos J, Righetti T, Sandrock D (2011) The role of vegetation in regulating stormwater runoff from green roofs in a winter rainfall climate. Ecol Eng 37(4):595-600. doi:10.1016/j. ecoleng.2010.12.020

Seidl M, Gromaire MC, Saad M, De Gouvello B (2013) Effect of substrate depth and rain-event history on the pollutant abatement of green roofs. Environ Pollut 183:195-203. doi:10.1016/j.envpol. 2013.05.026

Sempel F, Gorbachevskaya O, Mewis I, Ulrichs C (2013) Fine dust binding potential of extensive roof top greening systems compared to roof gravel cover. Gesunde Pflanz 65(3):113-118. doi:10.1007/ s10343-013-0305-6 
Song U, Kim E, Bang JH, Son DJ, Waldman B, Lee EJ (2013) Wetlands are an effective green roof system. Build Environ 66:141-147. doi: 10.1016/j.buildenv.2013.04.024

Teemusk A, Mander U (2007) Rainwater runoff quantity and quality performance from a greenroof: the effects of shortterm events. Ecol Eng 30(3):271-277. doi:10.1016/j.ecoleng. 2007.01.009

Teemusk A, Mander U (2011) The influence of green roofs on runoff water quality: a case study from Estonia. Water Resour Manag 25(14):3699-3713. doi:10.1007/s11269-0119877-z

Toland DC, Haggard BE, Boyer ME (2012) Evaluation of nutrient concentrations in runoff water from green roofs, conventional roofs, and urban streams. Trans Asabe 55(1):99-106

USEPA (2013a), Basic information, Climate Change. http://www. epa.gov/climatechange/basics. Last accessed 28 February 2014

USEPA (2013b), Carbon dioxide capture and sequestration, Climate Change, http://www.epa.gov/climatechange/ccs/index.html. Last accessed 28 February 2014

Vijayaraghavan K, Joshi UM, Balasubramanian R (2012) A field study to evaluate runoff quality from green roofs. Water Res 46(4):13371345. doi:10.1016/j.watres.2011.12.050
Wang XC, Zhao XH, Peng CR, Zhang XB, Wang JH (2013) A field study to evaluate the impact of different factors on the nutrient pollutant concentrations in green roof runoff. Water Sci Technol 68(12): 2691-2697. doi:10.2166/Wst.2013.547

Whittinghill LJ, Rowe DB, Cregg BM (2013) Evaluation of vegetable production on extensive green roofs. Agroecol Sust Food 37(4): 465-484. doi:10.1080/21683565.2012.756847

Wong NH, Cheong DKW, Yan H, Soh J, Ong CL, Sia A (2003) The effects of rooftop garden on energy consumption of a commercial building in Singapore. Energ Build 35(4):353-364. doi:10.1016/ S0378-7788(02)00108-1

World Green Infrastructure Network Statistics (2009) http://www. worldgreenroof.org/Statistics.html. Last accessed 28 February 2014

Yang J, Yu Q, Gong P (2008) Quantifying air pollution removal by green roofs in Chicago. Atmos Environ 42(31):7266-7273. doi:10.1016/j. atmosenv.2008.07.003

Ye JJ, Liu CY, Zhao ZC, Li YQ, Yu SX (2013) Heavy metals in plants and substrate from simulated extensive green roofs. Ecol Eng 55:29-34. doi:10.1016/j.ecoleng.2013.02.012

Zhen J, Shoemaker L, Riverson J, Alvi K, Cheng MS (2006) BMP analysis system for watershed-based stormwater management. J Environ Sci Health Part a-Toxic/Hazard Subst Environmental Eng 41(7):1391-1403. doi:10.1080/10934520600657172 